ANALYSIS OF RELATIONSHIP BETWEEN ECONOMIC GROWTH, FISCAL POLICIES, AND DEMOGRAPHICS TO ISLAMIC HUMAN DEVELOPMENT INDEX IN INDONESIA (GRANGER CAUSALITY APPROACH)

\author{
Rukiah \\ IAIN Padangsidimpuan \\ e-mail: rukiahlubis@iain-padangsidimpuan.ac.id
}

\begin{abstract}
The purpose of the study is to analyze the relationship of Economic Growth, Fiscal Policies, and Demographics to the Islamic Human Development Index in Indonesia. The analysis method used the Granger Causality test in 33 representative provinces. Take sampling with the Criteria Purposive Sampling method. The results showed that there was a relationship between Economic growth to Demographic and Islamic Human Development Index. There was a relationship between Demographic to IHDI and fiscal policy in health and education. There was a relationship of Fiscal Policy in health to Fiscal Policy in education. The recommendation of the study was 1 . Increasing economic growth with equity to support the maximization IHDI in each region. 2. Optimizing Fiscal policy performance to improving public services in education and health so can impact on the high IHDI distributed in Indonesia.

Keyword: Islamic Human development Index, Economic Growth, Fiscal Policy, Demographics
\end{abstract}

\begin{abstract}
Abstrak
Tujuan dari peneltian ini untuk menganalisis hubungan antara pertumbuhan ekonomi, kebijakan fiskal, dan demografi terhadap Islamic Human Development Index di Indonesia, metode analisis yang digunakan adalah dengan memakai analissi granger causality test pada 33 provinsi yang mewakili, dengan memakai penarikan sample metode criteria purporsive sampling. Hasil penelitian menunjukkan bahwa Ada hubungan pertumbuhan ekonomi terhadap Demografi dan IHDI. Ada hubungan Demografi terhadap IHDI, kebijakan fiskal pendidikan dan fiskal kesehatan, Ada hubungan kebijakan fiskal kesehatan terhadap kebijakan fiskal pendidikan. Saran dari penelitian ini adalah, peningkatan pertumbuhan ekonomi dengan pemerataan di setiap daerah guna menunjang peningkatan IHDI, dan secara demografi , tercapainya pemerataan penyebaran jumlah penduduk productife. kebijakan fiskal yang mengarah pada optimalisasi peningkatan kinerja penggunaan anggaran agar tujuan peningkatan layanan pendidikan dan kesehatan
\end{abstract}


Vol. 6 No. 1 June 2020

masyarakat dapat tercapai dan berimbas pada tinggi dan meratanya IHDI di Indonesia.

Kata Kunci: Islamic Human development Index, Pertumbuhan Ekonomi, Kebijakan Fiskal, Demografi

\section{INTRODUCTION}

Indonesia is a developing country whose still to find a pattern of how to achieve the goal to be named the welfare of the community as a whole both physically and mentally. As a developing country, the progress of it can be seen from the Human Development Index (HDI). HDI is a report issued by UNDP every year containing human development achievements measured on a scale of 0 to 1 based on three indicators: longevity can be measured from life expectancy, knowledge can be measured from literacy and average years go to school, and the standard of living is measured from the real income per capita adjusted to the purchasing power parity of each country's currency to reflect the cost of living. (Eren and Kaynak, 2017).

United Nations Development Program data shows that the quality of Indonesian Human Development is far from what was expected. Indonesia's Human Development Index position is 116 on 178 countries in 2017 with middle criteria. this position is up compared to 2016 which was 133 from 188 countries. In region ASEAN, Indonesian are still below the Philippines, Singapore, and Malaysia. (UNDP Report, 2015; UNDP report 2016) Although Indonesia has an increasing HDI trend from year to year, the development gap in all provinces in Indonesia is still high, shown by the provincial gini ratio still below $5 \%$ (http: //www.bps.go.id, 2018). And there are HDI disparities in several provinces

Table I.1

Human Development Index (HDI) in Indonesian Provinces in 2017

\begin{tabular}{|c|c|c|c|l|}
\hline No & $\begin{array}{l}\text { Development } \\
\text { status }\end{array}$ & Criteria & $\begin{array}{l}\text { Number } \\
\text { of } \\
\text { provinces }\end{array}$ & Names of Provinces \\
\hline 1. & $0 \leq \mathrm{HDI} \leq 59,99$ & Low & 1 & Papua \\
\hline 2. & $60,00 \leq \mathrm{HDI} \leq 69,99$ & Middle & 18 & $\begin{array}{l}\text { Sulawesi Barat, Papua } \\
\text { Barat, NTT, Jambi, } \\
\text { Sumatera Selatan, } \\
\text { Bengkulu, Lampung, Kep. } \\
\text { Bangka Belitung, NTB, } \\
\text { Kalimantan Barat, }\end{array}$ \\
\hline
\end{tabular}




\begin{tabular}{|c|c|c|c|l|}
\hline & & & $\begin{array}{l}\text { Kalimantan Selatan, } \\
\text { Kalimantan } \\
\text { Kalimantan } \\
\text { Tengah, } \\
\text { Utara, } \\
\text { Sulawesi Tengah, Sulawesi } \\
\text { Tenggara Gorontal, } \\
\text { Maluku, Maluku Utara, }\end{array}$ \\
\hline 3. & $70,00 \leq \mathrm{HDI} \leq 79,99$ & High & 14 & $\begin{array}{l}\text { Aceh, Sumatera Barat, } \\
\text { Sumatera Utara, Riau, Kep. } \\
\text { Riau, Jawa Tengah, Jawa } \\
\text { Barat, Jawa Timur, Banten, } \\
\text { Bali, Kalimantan Timur, } \\
\text { Sulawesi Utara, Sulawesi } \\
\text { Selatan, DI. Yogyakarta }\end{array}$ \\
\hline 4. & $80 \leq$ HDI $\leq 100$ & Very & 1 & DKI Jakarta \\
\hline 5. & Total & & 34 & Province \\
\hline
\end{tabular}

Source: BPS Indonesia 2018 (data processed)

Table I.1 show that there is 1 province on a very high HDI, 14 provinces on the high HDI, 18 provinces on the medium HDI and 1 province on a low HDI. Middle HDI is dominated by provinces in eastern Indonesia, while high HDI and very high is dominated by provinces in western regions, namely Java and Sumatra, parts of Sulawesi and Kalimantan. In terms of the percentage of the number of provinces that have middle HDI at 52\%, high HDI at $41 \%$ Low, and very high HDI each at $2.9 \%$. We can conclude this condition that Indonesia's human development still has a gap in various regions in Indonesia.

Indonesia has almost $80 \%$ of the population is Muslim, certainly, a resource that should be empowered by accordance with Islamic values should be taken Falah as a development indicator (Anto, 2010: Chapra, 2008; Sahid Muhammad and Ahmad, 2013). Prosperity in the world is only temporary, and welfare in the hereafter is eternal according to Allah's command: "But you (unbelievers) choose worldly life, while the afterlife is better and more eternal" (QS Al A'laa ayah 16-17).

Achieving Welfare is the objectives of the Maqhasid Sharia on the Daruriyah Indicator, human development goal can be reconstructed based on the objectives of the Maqhasid Sharia to make new formula is named is Islamic Human Development Index (IHDI), where the development is to achieve welfare based on human needs in the aspects of Daruriyah (Necessity), Hajiyyah (Complement) and Tahsiniyah (Refinement). Daruriyah aspect can be developed 


\section{Fitrah}

$\Rightarrow$ Jurnal Kajian Ilmu-ilmu Keislaman

Vol. 6 No. 1 June 2020

back into a more complete indicator covering the achievement of material and non-material welfare, namely guard of Religion (Hifz Din), guard of soul (Hifz Nafs) guard intellectuality (Hifz Aql) and guard the property (Hifz Maal) the attainment of the need for five-goal is a representation of the achievement of physical and spiritual well-being. (Syatibi, 1997; Aamin ed. All, 2015; Mirakhor, 2007). Based on the five objectives of the Maqhasid Syariah, the researcher will adjust the indicators that can account for the five achievements as follows.

Table I.2

Holistic Welfare with its Proposed indicator

\begin{tabular}{|l|l|l|l|}
\hline $\begin{array}{l}\text { W } \\
\text { elfare }\end{array}$ & $\begin{array}{l}\text { Type of } \\
\text { Needs }\end{array}$ & aspect & Proposed Indicator \\
\hline $\begin{array}{l}\text { Material } \\
\text { Index }\end{array}$ & Mal & Property Ownership & GDP Index \\
\hline & & Distribution equity & Gini Index \\
\hline $\begin{array}{l}\text { Non } \\
\text { Material } \\
\text { index }\end{array}$ & Nafs & $\begin{array}{l}\text { Islamic Environment } \\
\text { Value }\end{array}$ & Property Index \\
\hline & Aql & & Education index \\
\hline & Nasl & & Family social index \\
\hline & Din & & Religiosity index \\
\hline
\end{tabular}

Source: Hendri Anto (2010)

Table 1.2 shows the indicators that we can reform a Human Development Index based on welfare achievements (falah) called Islamic Human Development Index. Result on the calculation of the Islamic Human Development Index for all provinces in Indonesia in 2010 to 2017 the following results were obtained:

Table I.3

Islamic Human Development Index (I-HDI) in Indonesia Provinces 2017

\begin{tabular}{|c|c|c|c|lr|}
\hline No & $\begin{array}{c}\text { Development } \\
\text { Status }\end{array}$ & Criteria & $\begin{array}{c}\text { Number } \\
\text { of } \\
\text { provinces }\end{array}$ & \multicolumn{1}{|c|}{ Names of Provinces } \\
\hline 1 & $0 \leq$ HDI $\leq 59,99$ & Low & 26 & $\begin{array}{l}\text { Banten, Sulawesi Barat, } \\
\text { Sumatera Selatan, } \\
\text { Kalimantar Tengah, Aceh, } \\
\text { Sulawesi Tengah, Jawa }\end{array}$ \\
\hline
\end{tabular}




\begin{tabular}{|c|c|c|c|c|}
\hline & & & & $\begin{array}{l}\text { Tengah, Sulawesi } \\
\text { Kalimantan Timur, NTB, } \\
\text { Riau, NTT, Sulawesi } \\
\text { Tenggara, } \\
\text { Gorontalo, Kep. Riau, } \\
\text { Kalimantan Selatan, Maluku, } \\
\text { Bengkulu, DIY Kalimantan } \\
\text { Barat, Bali, Jambi, Bangka } \\
\text { Belitung, Maluku Utara, } \\
\text { Papua Barat }\end{array}$ \\
\hline 2. & $\begin{array}{c}60,00 \leq \mathrm{HDI} \leq \\
69,99\end{array}$ & Middle & 2 & Sumatera Barat, Papua \\
\hline 3. & $\begin{array}{l}70,00 \leq \mathrm{HDI} \leq \\
79,99\end{array}$ & High & 2 & Jawa Barat, Sulawesi Selatan, \\
\hline 4. & $80 \leq \mathrm{HDI} \leq 100$ & $\begin{array}{l}\text { Very } \\
\text { High } \\
\end{array}$ & 3 & $\begin{array}{l}\text { DKI Jakarta, Jawa Timur, } \\
\text { Sumatera Utara }\end{array}$ \\
\hline 5. & Total & & 33 & Provinsi \\
\hline
\end{tabular}

source: Calculated result of I-HDI (by the Researcher) 2018

Table I.3 above shows that the calculation of the human development index based on the I-HDI formula turns out to be different from HDI. low I-HDI dominate around 78\% from all Provinces, while middle and high IHDI was 6\% and very high I-HDI were around 9\%. I-HDI result is a different achievement with HDI dominate. In I-HDI, it appears DKI Jakarta, East Java, and North Sumatera are provinces on the very high I-HDI in 2017, while in achieving HDI (compare with table I.1), 1 province is in very high, namely DKI Jakarta, 14 provinces are in the high and 18 provinces are in the middle and 1 province is in the low HDI. Difference achievement may appear because I-HDI indicators used more comprehensive than HDI.

Human development in a country is related and interconnected with other economic variables such as economic growth, fiscal policy, and Demography. In terms of fiscal policy, the extent to which government policy is to budget the state expenditure on education and health because the basic requirement for development is that people get adequate access to education and health. (Widodo, 2011; Mustafa, 2017; Todaro and Smith, 2003). In 2017 Indonesia budget for education and health is still capable of budgeting $20 \%$ and $5 \%$ from the entire APBN (http://www.kemenkeu.go.id, 2017). These amounts will also impact on the ability of the region to optimize it, given that fiscal policy has also entered into regional autonomy 


\section{Fitrah \\ I Jurnal Kajian Ilmu-ilmu Keislaman \\ Vol. 6 No. 1 June 2020}

The level of education and public health that is expected to contribute to the development and improvement of the Islamic Human Development Index will be achieved if the peoples have high income per capita, the ability to consume and save. Savings in financial institutions can increase investment in development. Thus, the investment will drive the real sector and business. If the real sector and business move, economic growth will increase, and state income through taxes will also increase, and so on the economic cycle goes (Soledad ed, all, 2016; Ayu Bhakti, 2013). In 2010 Indonesia's economic growth was at the level of $6.8 \%$, there was a tendency to continue to decline and only survive at the level of 5.1\% in 2017, (http://www.bps.go.id, 2018), and This macro growth will greatly impact development in each province.

Unequal development and economic growth will also have an impact on the composition of the population of productive in an area, where the phenomenon of uneven development will result in the accumulation of productive residents in an area due to urbanization and shifting the age composition of the population on area. Based on prediction From 2020 to 2030, Indonesia will have a Demographic Bonus where the number of productive populations is greater than the number of unproductive population (http://www.Kompasiana.com), and this condition is actually a large capital in development if the country can utilize it. From the description above, we can draw a problem, how is the mutual relationship between the Islamic Human Development Index, economic growth, fiscal policy, and demographics in Indonesia?

\section{RESEARCH METHOD}

Based on objectives study, the methods and data analysis techniques used by using a causality approach, where each variable can act as an endogenous and exogenous variable, and try to see patterns of relationships between variables. The sampling technique used is Non-Probility sampling (Non-Random Sampling) in the form of purposive / judgment sampling which is based on certain criteria determined by researchers because it is considered to have the best position that can provide the information needed by researchers. This study uses pooling data which is a combination of time series data and cross-section data. Pooling data can be analyze using the Vector Auto Regression (VAR) method and later will produce a complete causal test (Granger Causality Test) 
Variable data for each province. Complete data have 33 provinces and the year of observation in this study was 8 years from 2007 to 2017.

Causality relationships are very necessary for any field of science to formulate a theory, but a cause and effect relationship is not something that is easy to test, is it true that something has a cause and effect or not. except with indepth and intense observations, not only testing whether there is a causal relationship, but the direction of the relationship is also very important to be tested (Ekananda, 2015). Causality is meant in a statistical framework, not based on philosophical concepts. Causality effect whose purpose is to see trends in the short and long term that are directed at the concept of forecasting. The concept of knowledge that tests the causality effect of various types of research variance can be done with the Granger Causality Test.

There are two main rules that are implied, first that future events cannot predict past events, thus a causal relationship can only occur where past events cause present or future events, secondly it is assumed the discussion will only have meaning for the causality of the group that stochastic (Ekananda, 2015). Granger's concept or approach states that the tendency of predictions is in line with causality, and the causal relationship is real and usually the effect will occur after the existence of a cause. The time series $X$ data is said to be Granger cause $Y$ series data if entering the previous $X$ value increases the forecast $Y$ value (with a smaller mean square error) than if only using the previous $Y$ value.

The Granger causality logic can be distinguished as follows:

a. One-way causality from X.. to Y.. (unidirectional causality from $x_{1}$ to $Y_{1}$ ) If $\sum b_{1} \neq 0$ dan $\sum d_{1}=0$

b. One-way causality from $Y$..to.. $X$ (unidirectional causality from $Y_{1}$ to $x_{1}$ ) if $\sum d_{1} \neq 0$ dan $\sum b_{1}=0$

c. Feedback Causality (bidirectional causality) if $\sum b_{1} \neq 0$ dan $\sum d_{1} \neq 0$

d. No causality if $\sum b_{1}=0$ dan $\sum d_{1}=0$

\section{RESEARCH RESULT}

Based on the results of pairwise granger causality testing using the Eviews 9, for all relationships between variables using lag 2. The test results can be seen in table III.1 based on the results of pairwise granger causality testing, we can analyze that if the probability value is $\leq 1 \%(0.01)$, or $<=5 \%(0.05) \leq 10 \%$ (0.10) then $\mathrm{H}_{\mathrm{o}}$ is rejected meaning there is causality between variables $\mathrm{X}$ and $\mathrm{Y}$ or 


\section{Fitrah \\ $\triangle$ Jurnal Kajian Ilmu-ilmu Keislaman \\ Vol. 6 No. 1 June 2020}

vice versa, if the probability value is $>1 \%(0.01)$, or $>5 \%(0.05)$ or also $>10 \%(0.10)$, then $\mathrm{H}_{\mathrm{o}}$ is accepted, meaning there is no causality relationship between variables $X$ and $Y$ or vice versa. Based on the test conditions above we can see that there are 5 equations whose probability values are $\leq 1 \%(0.01)$, or $\leq 5 \%(0.05)$, or $\leq 10 \%$ $(0.10)$ which indicates that there is causality between $X$ and $Y$ or vice versa.

Table III.1

Granger Causality Test

Pairwise Granger Causality Tests

Date: 05/01/19 Time: 23:06

Sample: 20102017 Lags: 2

\begin{tabular}{|lccl|}
\hline Null Hypothesis: & Obs & F-Statistic & Prob. \\
\hline Growth does not Granger Cause IHDI & 198 & 2.54102 & $\mathbf{0 . 0 8 1 4}$ \\
IHDI does not Granger Cause Growth & & 0.94310 & 0.3912 \\
\hline Fiscal_Health does not Granger Cause IHDI & 198 & 0.69470 & 0.5005 \\
IHDI does not Granger Cause Fiscal_Health & & 1.96003 & 0.1436 \\
\hline Fiscal_Education does not Granger Cause IHDI & 198 & 0.90037 & 0.4081 \\
IHDI does not Granger Cause Fiscal_Educ & & 1.96719 & 0.1426 \\
\hline Demographic does not Granger Cause IHDI & 198 & 3.20952 & $\mathbf{0 . 0 4 2 5}$ \\
IHDI does not Granger Cause Demographic & & 1.55337 & 0.2142 \\
\hline Fiscal_Health does not granger cause Growth & 198 & 0.92772 & 0.3972 \\
Growth does not Granger Cause Fiscal_Health & & 1.00291 & 0.3687 \\
\hline Fiscal_Education does not Granger Cause Growth & 198 & 1.00539 & 0.3678 \\
Growth does not Granger Cause Fiscal_Education & & 0.86608 & 0.4222 \\
\hline Demographic does not Granger Cause Growth & 198 & 1.29577 & 0.2761 \\
Growth does not Granger Cause Demographic & & 0.33925 & 0.7127 \\
\hline Fiscal_Education does not Granger Cause Fiscal_Health & 198 & 1.75643 & 0.1754 \\
Fiscal_Health does not Granger Cause Fiscal_Education & & 2.73104 & $\mathbf{0 . 0 6 7 7}$ \\
\hline Demographic does not Granger Cause Fiscal_Health & 198 & 4.81357 & $\mathbf{0 . 0 0 9 1}$ \\
Fiscal_Health does not Granger Cause Demographic & & 0.73584 & 0.4804 \\
\hline Demographic does not Granger Cause Fiscal_Education & 198 & 4.29246 & $\mathbf{0 . 0 1 5 0}$ \\
Fiscal_Education does not Granger Cause Demographic & & 0.78717 & 0.4566 \\
\hline
\end{tabular}

Source: data process 2019 with Eviews 9

Based on table III. 1 above show the 20 statements of causality and 15 statements that have a probability value $>1 \%(0.01),>5 \%(0.05)>10 \%(0.10)$ means there is no causality relationship between variables and 5 equations of probability values $<1 \%(0.01),<5 \%(0.05),<10 \%(0.10)$ means that there is a causality relationship between variables $X$ and $Y$ and vice versa. While one equation has a probability value of $\leq 0.10$. The following table summarizes the results of the Granger causality test equation 
Table III. 2

Granger Causality Summarizes

\begin{tabular}{|lrrr|}
\hline $\begin{array}{l}\text { Pairwise Granger Causality Tests } \\
\text { Date: 05/01/19 Time: 23:06 } \\
\text { Sample: 2010 2017 Lags: } 2\end{array}$ & & & \\
\hline Null Hypothesis: & & & \\
\hline Growth does not Granger Cause IHDI & F-Statistic & Prob. \\
\hline Demographic does not Granger Cause IHDI & 198 & 2.54102 & $\mathbf{0 . 0 8 1 4}$ \\
\hline Fiscal_Health does not Granger Cause Fiscal_Education 198 & 2.73104 & $\mathbf{0 . 0 6 7 7}$ \\
\hline Demographic does not Granger Cause Fiscal_Health & 198 & 4.81357 & $\mathbf{0 . 0 0 9 1}$ \\
\hline Demographic does not Granger Cause Fiscal_Educ & 198 & 4.29246 & $\mathbf{0 . 0 1 5 0}$ \\
\hline
\end{tabular}

Source: Data process 2019 with Eviews 9

Table III.2 show that there are 5 statements that have a Granger causality relationship, namely:

1. There is a causality relationship between economic growth to IHDI

2. There is a causality relationship between the population of Produktife (Demography) and IHDI

3. There is a causality relationship between Productive Population (Demography) and the budget expenditure in the health sector (Fiscal_Health)

4. There is a causality relationship between expenditure in the health sector (Fiscal_Health) and expenditure in the education sector (Fiscal_Education)

5. There is a causality relationship between Productive Population (Demography) and the budget expenditure in education (Fiscal_Education)

\section{DISCUSSION}

Granger Causality test results show that there is a causality relationship between economic growth with IHDI (Olalekan David, 2019; Agustina, Rochaida, Ulfa, 2016). Equitable economic growth will increase people's income and its implications for the ability to consume and access good education and health services.

The formation of human resources is based on the process of gaining knowledge. Because of the different abilities of individuals, each has the distinctiveness of forming human capital. Based on empirical studies the process of forming human resources is influenced by demographic, sociodemographic, 


\section{Fitrah \\ $\exists$ Jurnal Kajian Ilmu-ilmu Keislaman \\ Vol. 6 No. 1 June 2020}

economic, economic, and ecological organizations. Indicators such as natural population growth and life expectancy, changes in population income or health status, economic growth rates, labor demand, and other factors that influence the formation of human resources (Ciutiene, and Lailaite, 2015).

While there is a causality relationship between demographics (productive population) and IHDI. Human development is not only determined by factors of education, health, income, human rights, social justice but also influenced by a number of demographic factors such as educational attainment and gender composition also education, and training obtained by residents of a country. (Oledipo and Rahman. 2016; Ciutiene, and Lailaite, 2015).

There is a demographic relationship (number of productive population) with fiscal policy in health (Fiscal_Health). The development goals set out in each region cannot be separated from central and regional budget policies on how to allocate budgets to improve the quality of life of the people. The high and low number of productive population is certainly very closely related to how the government conducts policies in the health sector. In addition, development goals will also be obtained by efforts to improve the health of the population, health is interpreted as physical, mental, social and spiritual care of an individual to appear active in society (Kasule $\mathrm{OH}, 2008)$.

Government efforts in reducing maternal and child mortality, health promotion to remote areas throughout Indonesia, improvement of Posyandu services, prevention of poor demand, access to health insurance, improvement of hospital facilities and infrastructure at the central and regional levels, improving the quality of medical personnel, all of these programs will be implemented well if the budget allocation for improving public health can be maximized. As it is known, that the health budget from the State Budget in 2017 is around $5 \%$ of the total State Budget. (http://www.kemenkeu.go.id, 2017). The health budget is allocated through Central Government Expenditures, both ministries and institutions, Transfers to Regions and Village Funds, and financing. Meanwhile, the percentage of the workforce to the working-age of Indonesia's population for 2017 is around $69.20 \%$.

There is a relationship between the number of productive population (demography) with spending on education (Fiscal_Education). The education budget as stated in the national budget for 2017 is still maintained at $20 \%$ of the total state budget, the allocation of the education budget for each region is 
certainly different depending on the ability of the region to allocate it (Syahrir et al, 2013). The implementation of the allocation of funds from the center to the regions through the balance fund, especially through the General Allocation Fund (DAU), gives regional freedom to allocate it. The main educational goal is to improve the quality of human resources so that they can compete and become the motor of long-term development (Beik, 2016) and the main pioneers to encourage national development are those who are at the productive age level of around 15 to 65 years, and among these age phases, the most important is the working-age population. The working-age population will be able to absorb employment opportunities if they have adequate education and skills. In 2017, the percentage of the workforce age to work age by agrigetation was $69.20 \%$ and the percentage of the population working for employment was an average of 94.50\%. (http://www.bps.go.id)

finding in this study there is no relationship between education and health fiscal policies on IHDI. shows that regional fiscal policies in the education and health sectors have not had a significant impact on the direct development of IHDI in Indonesia. This condition shows that fiscal policy is directly related to demographics (productive population) and that productive population will increase IHDI.

\section{CONCLUSION}

There is a causality relationship between economic growth and an increase in IHDI, with a probability value of 0.0814 . This statement shows that if the economy grows, people's incomes will be high and have an impact on the ability to access health and education services and will have implications for increasing the Islamic Human Development Index (material and non-material needs will be more balanced)

There is a causality relationship between Demographics (productive population) and the Islamic Human Development Index, with a probability of 0.0425. This statement shows that the increasing number of productive population will contribute to the movement of the economy and has implications for the improvement of IHDI, if the government can provide adequate employment, but will be the opposite if large productive populations do not have employment opportunities and consequently become a state burden, and IHDI will decrease. 


\section{Fitrah \\ I Jurnal Kajian Ilmu-ilmu Keislaman \\ Vol. 6 No. 1 June 2020}

There is a causality relationship between productive population and health fiscal policy with a probability of 0.0677 . This statement shows that a large productive population is part of the success of health sector development, and vice versa, a productive and creative population will contribute to the ongoing development of the health sector.

There is a causality relationship between fiscal policy in education and health, with a probability of 0.0091 . This statement shows that fiscal policy in education and health is a basic policy for the achievement of public welfare if successful educational development will impact on community health development.

There is a causality relationship between demographics (productive population) and education fiscal policy, with a 0.0150 probability, this statement shows a high productive population is the result of the educational development process and vice versa.

\section{RECOMMENDATION}

Health and education fiscal policies should be able to improve the quality of human development in Indonesia, which is marked by the high and evenly distributed achievement of the Islamic Human Development Index throughout Indonesia. With a fiscal policy right on target with a performancebased budgeting paradigm and the application of Good Governance in the implementation of development management in Indonesia, so as to avoid the large amount of development budget funds that are leaking

The education system must be more directed towards the goal of learning achievement, where the internalization of spiritual and moral values is more emphasized so that development actors are also able to set a role model. Development in the health sector also in order to be able to provide health services to all people both at central and regional levels, affordability of cheap and guaranteed health services is one of the conditions for achieving good human quality.

Equitable development with a pattern of achieving economic growth and equity (Economic Growth with Equity). By exploring the potential of regions that have not been optimized and moving the real and monetary sectors in a balanced manner. Maximizing the function of Islamic financial institutions, in order to become a pioneer of the economic movement of the community. With 
the even distribution of development cake demographically, it will reduce the accumulation of productive residents in an area.

\section{REFERENCES}

Adi Widodo dkk. Analisis Pengaruh Pengeluaran Pemerintah di Sektor Pendidikan dan Kesehatan terhadap Pengentasan Kemiskinan melalui Peningkatan Pembangunan Manusia di Provinsi Jawa Tengah. Jurnal Dinamika Ekonomi Pembangunan, Volume 1, Nomor 1 juli 2011

Agustina, Eka dkk, 2016. Pengaruh Pengeluaran Pemerintah Daerah sektor Pendidikan dan Kesehatan terhadap Produk Domestik Regional Bruto serta Indeks Pembangunan Manusia di Kalimantan Timur. INOVASI : Journal Ekonomi Keuangan dan Manajemen, Vol. 12 (2)

Amin, Ruzita Mohd dkk, 2015. The Integrated Development Index (I- Index) a new comprehensive approach to measuring human development. ResearchGate, Blomsbury Qatar Foundations journal vol.2

Anto, Hendri MB. 2010. Introduction an Islamic human development Indeks (I- HDI) to measure development in OIC countries" IRTI journal, Vol. 19 No. 2

Al-Qur'an dan Terjemahannya Departemen Agama RI (Semarang : Cv. As Syifa) 2001

Beik, Irfan Syauki dan Laily Dwi Arsyianti, 2016. Ekonomi Pembangunan Syariah. Jakarta : Rajawali Press

Castaño, María Soledad ed, all. The Effect of Public Policies on Entrepreneurial Activity and Economic Growth. Journal of Bussines Research, Elsevier 2016 


\section{Fitrah \\ $\Rightarrow$ Jurnal Kajian Ilmu-ilmu Keislaman \\ Vol. 6 No. 1 June 2020}

Chapra, M. Umer. 2008. The Islamic Vision of Development in the Light of Maqāsid Al-Shari’’ah. Working paper, ResearcGate

Chapra, M. Umer. 2008. Ibn Khaldun's theory of development: Does it help explain the low performance of the present-day Muslim world? The Journal of SocioEconomics 37

Ciutiene, Ruta, and Rasa Lailaite. A Development of Human Capital in the Context of an Aging. Procedia - Social and Behaviour Sciences p. 753- 757. 2015

David, Oladipo Olalekan. 2019. Nexus Between Telecommunication Infrastructures, Economic Growth and Development in Africa: Panel vector Autoregression (PVAR)Analysis. Telecommunication Policy. Elsevier ltd

Ekananda, Mahyus. Analisis Ekonometrika Data Panel. Edisi 2. Mitra Wacana Media, 2016

Eren, Miraç, and Selahattin Kaynak. 2017. An evaluation of EU member states according to human development and global competitiveness dimensions using the multi-period grey relational analysis (MP-GRA) technique Application Vol. 7 No. 1, pp. 60-70 @ Emerald Publishing Limited.

Human Development Report, Human Development for Everyone, New York: UNDP 2016

Ika, Syahrir, dkk., Risiko Fiskal Daerah: Menjaga Kesehatan Fiskal dan Kesinambungan Pembangunan Cetakan Kedua, Solo: Era Adicitra Intermedia, 2013

Kasule, O.H "The concepts of health: an Islamic perspective", paper presented at The Annual Training for Better organization and Islamic Health Conference organized by the Islamic Medical Faculties of Indonesia, Universitas Islam Sultan Agung Semarang, 20 December. 2008

Mirakhor, Abbas. 2007. "A Note on Islamic Economics," Islamic Research and Training Institute, IDB Lecture Series No.20. Islamic Development Bank

Mohammad, Nur Sahid dan Sanep Ahmad. 2013. Pembangunan Menurut Perspektif Islam, satu analisis Awalan Development from Islamic perspective: an Interim analysis). Prosiding PERKEM VIII jilid 1

Mustafa, Ghulam, ed, all. 2017. Growth, Human Development, and Trade: The Asian Experience. Economic Modelling. Elsevier

Oladapo, Ibrahim Abiodun dan Asmak Ab. Rahman. 2016. Re-counting the determinant factors of human development: a review of the literature 
HumanomicVol.32 No. 2, pp. 205-226 Emerald Group Publishing Limited.

Sadeq, Abul Hasan. 2016. Development Issues in Islam. International Islamic University Malaysia

Syatibi, Abu Ishaq. 1997. Al-Muwafaqat, jilid 2, Beirut: Darul Ma'rifah

Todaro, Michael P. dan Stephen C. Smith. Pembangunan Ekonomi di Dunia Ketiga edisi 8Jakarta: Erlangga 2003

http://www. Kemenkeu.go.id/ APBN 2017

http://Www. Bps.go.id

http://edukasi.kompas.com/read/2018/10/30/08000011/5-negara-dengan-alokasianggaran-pendidikan-terebesar?page=all diakses 12 Agustus 2019 


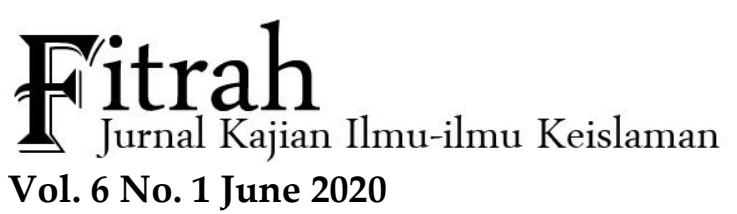

\title{
EFFECTIVENESS OF VILLAGE FUND MANAGEMENT ON INCREASING COMMUNITY WELFARE WITH MANAGEMENT RELIGIOSITY BEHAVIOR AS MODERATING VARIABLES
}

\author{
Aswadi Lubis \\ IAIN Padangsidimpuan \\ e-mail: aswadilubis63@gmail.com
}

